\title{
EL MITO DE LOS GEMELOS
}

por Carlos Antonio López y

León Cadogan

Teletransmbyáguaranizado

al portunhol selbagem

por Douglas Diegues*

* Douglas Diegues é poeta e organizador e tradutor da antologia de

poesia guarani Kosmofonia mbya guarani, em co-autoria com o an-

tropólogo e musicólogo Guillermo Sequera, estudo que será conside-

rado um dos mais sérios sobre as poéticas ditas indígenas no Brasil. 


\section{Charïa era}

sumamente inteligente

porque non

tenía ombligo.

Non había

sido parido.

Como los dioses,

había aparecido,

Ojerá,

espontaneamente,

y acompanhava siempre

a Pa'í Rete Kuaray.

Pa'í quis que en cada árbol houvesse um nicho, uma kasita di abeja.

Pero Charïa fue kontra, dizendu ser mejor que los hom-

bres ralassem kuando quisessem enkontrar miel.

Pa'í quis que todos los árboles dessem frutos.

Pero Charïa também se opôs, alegando que los hombres

fikariam perezozos.

Pa'í propuso que las plantaciones madurassem num sólo dia Pero Charïa argumentou ser necessário que algunos meses volassem antes que las plantaciones amadurecessem.

Pa'í inbentou uma enguia.

Charïa fabrikou una víbora venenosa.

Pa'i inbentou un Pyndó.

Charïa inventou una planta igual em todo, pero llena di espinhos desde los piés hasta las hojas: el Kokotêro.

Pa'i tinha um hijo. Kuando queria comer peces, mandava u minino lavar sus piés en algum Rio. Los peces se intoxicabam. Pa'i ficaba non mais con lo que necessitaba.

Charïa pediu emprestado u minino. Y lo matou a pauladas. $Y$ lo atirou al água. $Y$ los peces morreram intoxikados. $Y$ el minino si transformou en Timbó, para que todo mundo tivesse mais trabajo cazando y depois macetando Timbó kuando quisesse comer peces.

Pa'i tinha otro hijo. Quando queria komer karne, mandaba u minino imitar grito di kapivara.

Ele imitaba. Uma kapivara corriendo se aproximaba. Com un flechazo, u minino la mataba.

Charïa pediu emprestado o minino y mandou que imitasse.

El minino imitou.

Uma kapivara corriendo si aproximou.

Kuando chegou biem pertinho,

Charïa empurrou o minino kontra ella

El minino virou karrapato gigante.

ficou grudado en la kapivara que,

corriendo, cada vez mais si afastaba

Assim ficaria miedroza y esquiva,

y todos teriam di ralar kuando

quisessem morfar

karne di kapivara.

Pa'í tinha uma hermosa hija. 
Charïa si apassionou. Y pediu a minina.

Pa'í la entregou advertindo que deberia kuidar bem la minina.

Pero Charïa si komportou di manera indecente como si fosse um berdadero "paraguayo-perro". Y al cruzar el Rio, la hermosa Yiyi- iplim! - sumiu inexplicabelmente. [1]

Charïa foi hasta Pa'í reclamar disso.

Pero Pa'í ya havia decidido deshacérse de Charïa.

Y dijo que unikamente

la poderia enkontrar

el que trouxesse a la cabeza

un Akãpychía ou un Jegwaká.

A pedido di Charïa,

Pa'í hizo uno de esos adornos,

en lo qual enfiou

uma gota

del Fuego

que Nunka

se Acaba,

Tatá Marane'y.

Charïa se puso el adorno

y foi atrás de la encantadora Yiyi desaparecida.

Non mucho depois Charïa empezou a sentir

que sua kabeza estaba en llamas.

Quis livrar-se del Akãpychía, pero non lo conseguiu.

Entrou num Rio estilo Panambi'y, pero non funcionou.
Enfiou la cabeza num brejo, pero el Fuego non apagou.

Empezou a correr desesperadamente. Y perto del Paraná

virou Cinzas.

Pa'í lo seguiu y soplou sobre las Cinzas.

Las Cinzas viraram pequenos ferozes moskitos Mbarigwi y Mbigwyque que solamente atakam por la noche y millones di otros insetos que llovian sobre Charía.

Apareceu una porrada de bichos para distrair los moskitos- piranhitas enkuanto el tiempo passaba. Pero todavia los moskitos le kilombeavam.

Charïa voltou correndo al Ywy Mbyte, acossado por moskitos de los mais variados tipos.

Los moskitos lo enloqueciam cada vez mais un pokito.

De dia - Mbarigwi.

De noite - Mbigwy.

Desesperadamente le gritó a suo padre que non sabia mais a que ou a quem recorrer.

Pa'í apareceu de repente.

Y dijo que lo que estaba akontecendo era algo muy insignificante.

Y le entregou um recipiente lleno de Rocío, Ychapy

Marane'ÿ, para que passasse Rocío por su kuerpo detonado y renobasse la sangre que los moskitos-piranhitas le haviam rapiñado.

Assim lo hizo

Y nasceu otra vez. 

Nota de León Cadogan
[1] En otras bersiones deste mito
Pa'í Kuaray (el Héroe Solar) crea
expressamente imágenes de

mujeres para confundir a Charïa.
Y deixou el recipiente nel suelo.

Uno de los bichos que lo rodeabam atropelou el recipiente

partiéndolo en mil pedazitos diferentes.

Y Rocío se derramou.

Y com la Tierra se mixturou.

Y nasceu una Y'á (Hy’á)

Y nasceu um Takwá.

$Y$ destas duas

plantitas selbagens

nasceu lo que hoy se chama humanidade. ${ }^{4}$ 